\title{
RAPD and ERIC-PCR coupled with HRM for species identification of non-dysenteriae Shigella species isolated from clinical specimens; As a potential of alternative method
}

\section{Babak Pakbin}

University of Tehran Faculty of Veterinary Medicine

Afshin Akhondzadeh Basti ( $\sim$ aakhond@ut.ac.ir)

University of Tehran Faculty of Veterinary Medicine

Ali Khanjari

University of Tehran Faculty of Veterinary Medicine

Leila Azimi

Shaheed Beheshti University of Medical Sciences

Abdollah Karimi

Shaheed Beheshti University of Medical Sciences

\section{Research article}

Keywords: Shigella; RAPD; ERIC; HRM; PCA; Species identification method

Posted Date: July 17th, 2020

DOI: https://doi.org/10.21203/rs.3.rs-43901/v1

License: (c) (1) This work is licensed under a Creative Commons Attribution 4.0 International License.

Read Full License 


\section{Abstract}

Background: Species identification of Shigella isolates are so prominent for epidemiological studies and implementing infection prevention strategies. We developed and evaluated RAPD and ERIC-PCR assays coupled with HRM for differentiation of non-dysenteriae Shigella species as potential alternative methods. isolation of eighteen Shigella strains from faecal specimens collected from children under 2 years old with diarrhea symptom ( $n=143)$, species of the isolates were identified by slide agglutination assay as the golden standard method. Species of isolates were identified using developed RAPD-PCRHRM and ERIC-PCR-HRM assays and differentiation of data sets obtained from difference plots of HRM was implemented by PCA as a dimension reduction method then sensitivity and specificity of the methods were evaluated using ROC curve.

Results: Consequently, we found that RAPD-PCR-HRM with sensitivity and specificity of 100 and $85 \%$ respectively is significantly more suitable for identification of non-dysenteriae Shigella species. However, sensitivity and specificity of ERIC-PCR-HRM were evaluated 33 and $46 \%$ respectively.

Conclusion: Regardless of inherent poor reproducibility of DNA fingerprinting based methods, RAPD-PCRHRM assay can be considered as a potential of alternative method for species identification. Also, HRM technique used in this study is more rapid, inexpensive, and sensitive than gel electrophoresis for characterization of PCR amplicons.

\section{Background}

Shigella is a facultative anaerobe, gram-negative bacilli belonging to the Enterobacteriaceae family with intestinal and extraintestinal pathogenicity in human (Shigellosis). Four species (with different serotypes) have been characterized for this genus including: S. sonnei, S. flexneri, S. boydii, and S. dysenteriae. Shigella species cause mild to severe diarrhea in adults and children (up to $28 \%$ fatality rate in children with severe symptoms) as intestinal pathogens; however, $S$. dysenteriae type 1 lead to hemorrhagic uremic syndrome (HUS) because of releasing Shiga-toxin; it is regarded as the only extraintestinal disease caused by this genus [1]. There are significant differences between the severity and type of the gastrointestinal disorders triggered by Shigella species. Also, the geographical distributions of prevalence rate of Shigella species are considerably varied among developing and industrial countries [2]. Epidemiological studies revealed that identification of Shigella species plays a crucial role for providing acceptable clinical investigation and tracing of the outbreaks generated by this pathogen [3]. Therefore; to support the epidemiological investigation of shigellosis outbreaks especially among high-risk population as well as infant cases, different serological, molecular and immunological assays have been developed for identification of Shigella species. The most prominent challenge of Shigella species identification is differentiating all species from each other [4]. However; differentiation of Sh. dysenteriae is more practicable because of harboring stx gene as the specific marker [5]. Some of these identification methods consist of DNA hybridization, multiplex PCR, whole genome sequencing, immunocapture PCR, 
standard. However, many of these methods, despite the optimization, are too expensive and complicated to be employed in clinical labs. Thus, new methods as well as more affordable and user-friendly assays with acceptable specificity and sensitivity are still needed to be developed and optimized [6].

DNA fingerprinting techniques are carried out for characterization and typing of microbial genomes. These methods are divided into two main categories: sequencing-based assays such as multi-locus sequence typing (MLST), repetitive element sequence-based (Rep-PCR), microarray, comparative hybridization, and whole genome sequencing; and non-sequencing-based techniques e.g. random amplification polymorphism DNA (RAPD-PCR), enterobacterial repetitive intergenic consensus (ERICPCR), pulsed field gel electrophoresis (PFGE), and amplified fragment length polymorphism (AFLP) assays [7]. Obviously, sequence-based typing techniques are more expensive, time consuming, and complicated than other group of assays [8]. DNA PCR fingerprinting methods e.g. RAPD and ERIC have been widely used as genotyping assay for enterobacterial foodborne pathogens. However, these techniques have been developed for species identification of some bacterial and fungal strains regardless of species-specific sequences [9]. Because of the complicated PCR products of RAPD and ERIC-PCR, statistical and mathematical analysis of the results are suggested to be carried out for further genomic characterization and species identification. Also; requiring characterization of the PCR products of RAPD and ERIC-PCR, usually implemented by electrophoresis on agarose gel, is considered as another challenge of these methods for species identification [10].

High resolution melting curve analysis (HRMA) provides characterization of PCR products as a rapid alternative assay of gel electrophoresis with higher precision and differentiation potential of PCR products with the same size [11]. This property of HRMA makes it considerable to be employed for analysis of the complicated PCR products as well as in genotyping and DNA fingerprinting protocols. PCR molecular typing methods such as RAPD coupled with HRMA has been developed successfully to characterize microbial strains in intra-serovar levels and for species identification [12]. However, use of PCR based DNA fingerprinting methods coupled with HRMA despite many advantages for serotype and species identification of microbial strains is limited to a few researches [13]. In the present study, we developed RAPD and ERIC-PCR fingerprinting assay coupled with HRMA following analysis by principal component analysis (PCA) for identification of Sh. sonnei, Sh. flexneri and Sh. boydii strains after isolation from clinical specimens.

\section{Results}

So far, the most reliable method for identification of Shigella species is the gold standard assay by slide agglutination method using species-specific polyvalent antisera [14]. Despite higher sensitivity and specificity, this method is very expensive so many researchers have made efforts to develop new alternatives. Because of high-cost, complicated, and sensitive production process of monoclonal antibodies in serology-based methods, molecular assays as well as DNA based techniques are preferred to be developed for species identification of bacterial pathogens [15]. However, identification of $S$. 
regarded as a real challenge in comparison with identification of other species [16]. At the present study, we isolated and identified Shigella species in eighteen specimens (totally from 143 children under 2 years old with gastrointestinal disorder; $12.58 \%$ ) consisting of 11 S. sonnei, 3 S. boydii, and 4 S. flexneri isolates by golden standard method using culture-based technique for Shigella isolation and serologic assay for species identification (Table 1). After isolation by culture-based methods, we evaluated and developed RAPD and ERIC-PCR coupled with HRM methods as sensitive and specific alternative assays for Shigella species identification. Normalized and difference melting curves of isolates by RAPD-PCR-HRM are shown in Figs. 1 and 2, respectively. Because of extremely complicated PCR products amplified in RAPD, very complex melting curves were obtained after HRM step which made it impossible to categorize melting profiles by the instrument software algorithm [17]. Therefore; at the present study, we have employed a dimension reduction method, PCA as recommended by many researchers, to simplify analysis of this complex and huge data. PCA assay was performed on the data obtained from the output of HRM difference plot. PC 3D loading plot for difference melting curve data set of RAPD-PCR-HRM in species identification of Shigella isolates has been illustrated in Fig. 3. PCA plot showed that three distinctive groups as we considered three different species for Shigella isolates. Except one isolate of $S$. boydii, all species of isolated Shigella strains were identified correctly corresponded with the golden standard method for species identification by developed RAPD-PCR-HRM assay.

Table 1.

Shigella isolates identified in this study by golden standard methods

\begin{tabular}{lc}
\hline Species & Isolate name/ATCC number \\
\hline S. sonnei (SS1) & SSQI-2020-221 \\
S. sonnei (SS2) & SSQI-2020-222 \\
\hline S. sonnei (SS3) & SSQI-2020-223 \\
\hline S. sonnei (SS4) & SSQI-2020-224 \\
\hline S. sonnei (SS5) & SSQI-2020-225 \\
\hline S. sonnei (SS6) & SSQI-2020-226 \\
\hline S. sonnei (SS7) & SSQI-2020-227 \\
\hline S. sonnei (SS8) & SSQI-2020-228 \\
\hline S. sonnei (SS9) & SSQI-2020-229 \\
\hline S. sonnei (SS10) & SSQI-2020-230 \\
\hline S. sonnei (SS11) & SSQI-2020-231 \\
\hline S. sonnei (Reference-SSR) & ATCC 25931 \\
\hline S. boydii (SB1) & SBQI-2020-443 \\
\hline S. boydii (SB2) & SBQI-2020-444 \\
\hline S. boydii (SB3) & SBQI-2020-445 \\
\hline S. boydii (Reference-SBR) & ATCC 12030 \\
\hline S. flexneri (SF1) & SFQI-2020-328 \\
\hline S. flexneri (SF2) & SFQI-2020-329 \\
\hline S. flexneri (SF3) & SFQI-2020-330 \\
\hline S. flexneri (SF4) & SFQI-2020-331 \\
\hline S. flexneri (Reference-SFR) & ATCC 12022 \\
\hline
\end{tabular}


ERIC-PCR-HRM was evaluated as another assay carried out in this study for species identification of the same Shigella strains. Figures 4 and 5 showed normalized and difference plots of ERIC-PCR-HRM assay respectively for Shigella isolates. As the same as the fluorescence plots obtained from the RAPD-PCRHRM; because of extremely varied amplicon size and sequence, high complexity of melting profiles also does not allow normal analysis to be implemented for HRM data set in this procedure [17]. Difference plot output data of ERIC-PCR-HRM was analyzed for principal components determination with PCA. PC 3D loading plot of ERIC-PCR-HRM data set has been shown in Fig. 6. Seven species among eighteen isolates were recognized incorrectly showed that RAPD assay is more sensitive and specific than ERIC-PCR to identify Shigella species while they are coupled with HRM and analyzed by PCA. Sensitivity and specificity of an assay as the accuracy characteristics of a screening or identification test relative to a golden standard method are commonly evaluated by ROC curve [18]. ROC curves of the assays developed in this study for Shigella species identification including RAPD and ERIC-PCR-HRM assays are illustrated in Figs. 7 and 8, respectively. Sensitivity and specificity of the RAPD-PCR-HRM assay were observed 100 and $85 \%$, respectively. However, sensitivity and specificity of the ERIC-PCR-HRM technique were calculated 33 and $46 \%$ respectively regarding significant differences in comparison with the other assay. Nevertheless, these remarkable differences in methodological characteristics were predictable considering the results of PCA for each individual assay.

\section{Discussion}

DNA fingerprinting methods recently have been introduced as the assay for the purpose of microbial species identification. For the first time, Tulsiani et al. (2010) used high resolution melting curve analysis of RAPD for characterization of Leptospira strains to serovar level. They were successful to develop RAPD-HRM assay as an inexpensive and rapid method to identify different serotypes of Leptospira. However, melting profile analysis by Rotor-Gene 6000 series software package was used for clustering of the isolates and differentiating between the serotypes [19]. Miller et al. (2015) developed HRM-based assay for identification of Pasteurellaceae species by amplification of varied regions in $16 \mathrm{~s}$ rRNA sequence and they found this method sensitive and rapid for species identification [20]. Chen et al. (2019) also employed RAPD-HRM assay for differentiation of pathogenic and non-pathogenic Escherichia coli isolates from each other and they found it a sensitive, specific, and practical assay. There are few studies about species identification of bacterial strains using DNA fingerprinting methods coupled with HRM; however, many researchers investigated these methods for differentiating nonmicrobial species such as raw meat, animals, and plant species especially by RAPD-PCR-HRM assay. Also, RAPD-HRM assay has been used for genotyping of bacterial pathogens previously [17].

High resolution melting curve analysis of ERIC-PCR has not been developed and employed for genotyping and other molecular characterization of microbial genomes yet and the present study is the first one evaluated this method coupled with HRM as a molecular technique for diagnostic purpose [21]. During HRM procedure, saturating dyes bound to DNA then emit fluorescence because of dissociation of doublestrand DNA while the temperature is rising gradually then the emission is measured by a highly sensitive

Loading [MathJax]/jax/output/CommonHTML/fonts/TeX/fontdata.js lecular assay, it can be found that any 
difference as well as a single nucleotide polymorphism in amplicon sequences significantly changes the melting profile [22]. In DNA fingerprinting methods such as RAPD and ERIC-PCR assays, broad range of amplicons are produced throughout the PCR step. These complex PCR products are individually considered as a DNA marker for each organism and can be characterized by different methods [23]. Gel electrophoresis is commonly carried out for characterization of PCR products of DNA fingerprinting assay. HRM as a more rapid, inexpensive, sensitive and user-friendly method is used and more preferred for characterization of PCR products [24]. By HRM, RAPD and ERIC-PCR products are barcoded for better characterization and clustering of isolates in serotype and species identification. Because of the complex properties of these methods in PCR amplicon production, it is unclear that why one method is more practical, sensitive, and specific than the other one in species identification in comparison with the golden standard method [25]. At the present study, we found that RAPD-PCR-HRM assay is more appropriate and acceptable than ERIC-PCR-HRM method for Shigella species identification. However, this result may not be obtained for species or serotype identification of other microorganisms in the future studies. ERIC are repetitive sequences located on some specific genomic regions of Enterobacteriaceae family bacteria which are amplified during the PCR reaction [26]. In RAPD-PCR, randomly amplification is performed throughout the microbial genome on a wide range of different DNA regions which can be located on any probable position. Although both methods are based on random amplification, higher variation of amplified genomic regions in RAPD-PCR method may result in more efficient differentiation capability [27]. Limited genomic regions for DNA fingerprinting and barcoding classification makes ERIC-PCR inefficient to discriminate genomic differences among microbial strains and species. As previously investigated by many researchers, discriminatory index of RAPD was significantly higher than that of ERIC-PCR for genotyping of bacterial isolates. It is worthy to note that the most prominent drawback of DNA barcoding and fingerprinting methods based on random primer DNA typing such as RAPD and ERICPCR to identify microbial serotype and species is inherent poor reproducibility [28]. This main inherent problem has not been solved yet; also, we have not investigated on this challenge at the present study. However, it is more appreciated and suggested to improve and develop DNA fingerprinting methods with higher reproducibility in future studies. Nevertheless, we introduced RAPD-PCR-HRM assay as a potential alternative method for non-dysenteriae Shigella species identification; however, future studies with more sample size, and wide range of different molecular techniques are suggested to be implemented.

\section{Conclusion}

DNA fingerprinting methods usually are used for genotyping of microbial pathogens. These methods can be considered as the potential of alternative methods for differentiation of microbial serotypes and species. In this study, we developed and evaluated RAPD and ERIC-PCR methods coupled with HRM assay for identification of non-dysenteriae Shigella species isolated from clinical specimens. The authors attempted to analyze the data set obtained from the difference plots of HRM by PCA as a dimension reduction method to simplify the classification of melting profiles. We isolated eighteen Shigella strains in faecal specimens collected from children $(n=143)$ with gastrointestinal disorders and diarrhea cumntom thon cnonioe of tho ctrainc woro idontifiod hy clide agglutination assay as the golden standard Loading [MathJax]/jax/output/CommonHTML/fonts/TeX/fontdata.js 
method. Also, species of the isolates were identified by developed RAPD-PCR-HRM and ERIC-PCR-HRM methods analyzed with PCA. We found RAPD-PCR-HRM assay more appropriate than ERIC-PCR-HRM as the potential of alternative method for non-dysenteriae Shigella species identification with sensitivity and specificity of 100 and $85 \%$, respectively. Inherent poor reproducibility is the only disadvantage of all DNA fingerprinting based methods such as RAPD for genotyping or species and serotype identification which is suggested to be improved for the future studies.

\section{Methods}

\section{Fecal samples collection and reference bacterial strains}

Children under 2 years old with diarrhea symptom suspected to gastroenteritis ( $n=163$ ) in Qazvin, Iran, during December 2019 to February 2020 were referred to the central laboratory of Qods Children Hospital of Qazvin for microbiological investigation. As previously described by WHO Laboratory investigations manual of Enteric infections for faecal sample preparation, all suspected specimens were collected in disposable and clean containers then examined macroscopically and microscopically for color, mucus, consistency, and red blood cells [14]. All specimens were kept at $4{ }^{\circ} \mathrm{C}$ prior to bacterial isolation procedure. We also used S. sonnei ATCC 25931; S. flexneri ATCC 12022; and S. boydii ATCC 12030, purchased from Pasteur institute of Iran (Pasteur institute, Tehran, Iran), as Shigella reference strains in this study. All reference strains were activated by inoculation in Bovine Heart Infusion (BHI) broth and incubation at $37^{\circ} \mathrm{C}$ overnight.

\section{Shigella isolation and species identification}

All specimens were initially cultured on MacConkey agar and Salmonella-Shigella agar (SSA) media (Promedia, Spain) incubated aerobically for $24 \mathrm{~h}$ at $37^{\circ} \mathrm{C}$. Non-lactose-fermenting and H2S-negative colonies on MacConkey agar and SSA were isolated for biochemically identification. Biochemical tests consisted of Urease, Triple Sugar Iron (TSI), Motility, Siminous Citrate, and Indole tests. Biochemically confirmed colonies were further serologically analyzed for Shigella species identification. Serological identification was carried out using slide-agglutination test with DIFCO Shigella species specific antisera (Difco Lab, Michigan, USA) as the gold standard assay [15].

\section{Genomic DNA extraction}

Bacterial isolates and the reference strains were inoculated into LB broth then incubated at $37^{\circ} \mathrm{C}$ overnight. After centrifugation of the incubated LB broth tubes at 6000 RPM for $10 \mathrm{~min}$, the cell palette in each centrifuge tube were subjected to genomic DNA extraction employing Sinaclon gram-negative DNA extraction Kit (Sinaclon, Iran) according to the instructions described by the manufacturer. The quantity and quality of the extracted genome were evaluated using NanoDrop Spectrophotometer (Thermo Scientific, USA). Before PCR-HRM, concentration of all DNA templates was adjusted to $50 \mathrm{ng} . \mu \mathrm{L}-1$. 
In this study, we used the single random oligonucleotide primer 5- $C G C G T G \mathbb{C} A G$ - 3 for RAPD-PCR and species identification of isolated Shigella strains [16]. Each reaction tube contained $20 \mu \mathrm{L}$ of final volume, including $10 \mu \mathrm{L}$ of $2 \mathrm{X}$ HotStart EvaGreen PCR-HRM master mix (Solis BioDyne Co, Estonia), $0.5 \mu \mathrm{L}$ of RAPD primer $(20 \mathrm{pM}), 1 \mu \mathrm{L}$ of DNA template $(50 \mathrm{ng})$, and distilled deionized water to the final reaction volume. RAPD-PCR coupled with HRM assay was performed using Rotor-Gene 6000 real-time PCR instrument (Corbett, Australia) as follows: initial denaturation at $95^{\circ} \mathrm{C}$ for $5 \mathrm{~min} ; 35$ cycles of $95^{\circ} \mathrm{C}$ for $1 \mathrm{~min}, 36^{\circ} \mathrm{C}$ for $1 \mathrm{~min}$, and $4 \mathrm{~min}$ at $72^{\circ} \mathrm{C}$. Then HRM was performed between 70 and $95^{\circ} \mathrm{C}$ with continuous ramping $0.1{ }^{\circ} \mathrm{C} \mathrm{s}-1$. Fluorescence of melting profile was normalized between 80 and $95^{\circ} \mathrm{C}$ by Rotor-Gene 6000 series software version 1.7 (Corbett, Australia) then normalized and difference melting curves were obtained for each isolate.

For ERIC-PCR amplification two primers have been used including ERIC1R 5 - $A T G T \forall G C T \mathbb{C} T G G G G A T T C A C$ - 3 and ERIC2 5- $\forall$ GT $\forall$ GTGACTGGGGTGAGCG - 3 [16]. Both RAPD and ERIC primers used in this study previously were employed by researchers for DNA fingerprinting of enterobacterial pathogens. ERIC-PCR was performed in $20 \mu \mathrm{L}$ final reaction volume containing $10 \mu \mathrm{L}$ of $2 \mathrm{X}$ HotStart EvaGreen PCR-HRM master mix (Solis BioDyne Co, Estonia), $1 \mu \mathrm{L}$ of each primer (10 pM), $1 \mu \mathrm{L}$ of DNA template, and distilled deionized water to $20 \mu \mathrm{L}$. Rotor-Gene 6000 real-time PCR instrument (Corbett, Australia) also was employed for ERIC-PCR-HRM procedure. Thermal cycling program was initial denaturation step at $95^{\circ} \mathrm{C}$ for 5 min followed by 30 cycles of denaturation at $95^{\circ} \mathrm{C}$ for $1 \mathrm{~min}$, annealing at $52^{\circ} \mathrm{C}$ for $1 \mathrm{~min}$, and extension at $65^{\circ} \mathrm{C}$ for $8 \mathrm{~min}$. Afterwards, HRM was carried out from 70 to $95^{\circ} \mathrm{C}$ with $0.1^{\circ} \mathrm{C} \mathrm{s}-1$ ramping. Also, normalized and difference melting curves finally were achieved from the Rotor-Gene 6000 series software by fluorescence normalization of melting profile between 80 and $95^{\circ} \mathrm{C}$.

\section{Data analysis}

All difference curves obtained from Rotor-Gene 6000 series software were exported to Excel (Microsoft Office Excel software, Microsoft Corp., Redmond, USA) files then they were used as the input data of analysis. Principal components analysis (PCA) was employed for analysis and data categorization as a dimension reduction method by SPSS software version 23.0 (SPSS, Inc., Chicago, USA). Also, sensitivity and specificity of the methods have been evaluated using receiver operating characteristic (ROC) curve analysis by SPSS. All measurements and analysis were carried out in triplicates.

\section{List Of Abbreviations}

HUS: Hemorrhagic Uremic Syndrome; DNA: DeoxyriboNucleic Acid; rRNA: Ribosomal RiboNucleic Acid; PCR: Polymerase Chain Reaction; MALDI-TOF: Matrix Assisted Laser Desorption/lonization - Time Of Flight; RAPD: Random Amplification of Polymorphic DNA; ERIC: Enterobacterial Repetitive Intergenic Consensus; AFLP: Amplified Fragment Length Polymorphism; PFGE: Pulsed-Field Gel Electrophoresis; HRMA: High Resolution Melting Analysis; PCA: Principal Component Analysis; 3D: Three Dimensional; 


\section{Declarations}

\section{Ethics approval and consent to participate}

The study protocol for clinical samples was evaluated, reviewed, and approved by the ethics committee of National Institute for Medical Research Development (IR-NIMAD-REC.1397.204). There is not any medical care or treatment for consideration of informed consent.

\section{Consent for publication}

Not applicable.

\section{Availability of data and materials}

Not applicable.

\section{Competing interest}

The authors declare that they have no competing interest.

\section{Funding}

This research was implemented by the research grant dedicated from National Institute for Medical Research Development (NIMAD, http://nimad.ac.ir) of Iran with the grant number of 964212.

\section{Authors' contributions}

$\mathrm{BP}, \mathrm{AA}$ and $\mathrm{AK}$ designed the research project. $\mathrm{BP}, \mathrm{AKh}$ and $\mathrm{LA}$ performed all experiments and analysis. $\mathrm{BP}$ wrote the manuscript. AA and AK finalized and reviewed the manuscript. All authors investigated the final draft and approved the manuscript.

\section{Acknowledgements}

We greatly thank and appreciate all experimental technicians in Veterinary Campus, University of Tehran and physicians in Qazvin University of Medical Science for helping us performing laboratory analysis and sample collection.

\section{References}

1. Kotloff KL, Riddle MS, Platts-Mills JA, Pavlinac P, Zaidi AK: Shigellosis. The Lancet 2018, 391(10122):801-812.

2. Bennish ML, Ahmed S: Shigellosis. In: Hunter's Tropical Medicine and Emerging Infectious Diseases. Elsevier; 2020: 492-499.

3. Taneia N, Mewara A. Shiqellosis: epidemioloav in India. Indian J Med Res. 2016;143(5):565. 
4. Baker KS, Dallman TJ, Field N, Childs T, Mitchell H, Day M, Weill F-X, Lefèvre S, Tourdjman M, Hughes G. Horizontal antimicrobial resistance transfer drives epidemics of multiple Shigella species. Nature communications. 2018;9(1):1-10.

5. Gupta P, Dhaked RK. Immunological detection assays for recombinant Shiga toxin \& Shigella dysenteriae. Indian J Med Res. 2019;149(3):412.

6. Zhou K, Kuiling S, Friedrich AW, Kooistra-Smid AM. Evaluation of a culture dependent algorithm and a molecular algorithm for identification of Shigella spp., Escherichia coli, and entero-invasive E. coli (EIEC). J Clin Microbiol. 2018;56:e00510-8.

7. Kalendar R, Muterko A, Boronnikova S: Retrotransposable Elements: DNA Fingerprinting and the Assessment of Genetic Diversity. In: Methods in Molecular Biology: Molecular Plant Taxonomy. Springer; 2019.

8. Bertani G, Sardaro MLS, Neviani E, Lazzi C. AFLP protocol comparison for microbial diversity fingerprinting. J Appl Genet. 2019;60(2):217-23.

9. Shrivastava A, Singhal PK, Shrivastava P: Molecular Diagnosis of Enteric Bacterial Pathogens. In: DNA Fingerprinting: Advancements and Future Endeavors. Springer; 2018: 151-164.

10. Cui C, Li Y, Liu Y, Li X, Luo S, Zhang Z, Wu R, Liang G, Sun J, Peng J. Determination of genetic diversity among Saccharina germplasm using ISSR and RAPD markers. Comptes rendus biologies. 2017;340(2):76-86.

11. Farrar JS, Wittwer C: High-resolution melting curve analysis for molecular diagnostics. In: Molecular diagnostics. Elsevier; 2017: 79-102.

12. He P, Wang H, Luo J, Yan Y, Chen Z. A Real-Time PCR with Melting Curve Analysis for Molecular Typing of Vibrio parahaemolyticus. Current microbiology. 2018;75(9):1206-13.

13. Andini N, Wang B, Athamanolap P, Hardick J, Masek BJ, Thair S, Hu A, Avornu G, Peterson S, Cogill S. Microbial typing by machine learned DNA melt signatures. Scientific reports. 2017;7:42097.

14. Allen H, Mitchell HD, Simms I, Baker KS, Foster K, Hughes G, Dallman TJ, Jenkins C. Evidence for reinfection and persistent carriage of Shigella species in adult males reporting domestically-acquired infection in England. Clinical Microbiology and Infection 2020.

15. Sheikh AF, Moosavian M, Abdi M, Heidary M, Shahi F, Jomehzadeh N, Seyed-Mohammadi S, Saki M, Khoshnood S. Prevalence and antimicrobial resistance of Shigella species isolated from diarrheal patients in Ahvaz, southwest Iran. Infection drug resistance. 2019;12:249.

16. Murphy ER, Roßmanith J, Sieg J, Fris ME, Hussein H, Kouse AB, Gross K, Zeng C, Hines JV, Narberhaus F. Regulation of OmpA translation and Shigella dysenteriae virulence by an RNA thermometer. Infection and Immunity 2020, 88(3).

17. Chen Y, Lai Y, Shyu D, Chang Y, Chen Z, Liao Y, Pang C, Chang K. C-Terminal Part of GlutamateAmmonia-Ligase Adenyltransferase Gene Identified by RAPD-HRM with $3 \mathrm{H}$ Primer for E. Coli Screening. Folia Biol. 2019;65(2):88-100.

18. Narkhede S. Understanding AUC-ROC Curve. Towards Data Science 2018, 26. 
19. Tulsiani S, Craig S, Graham G, Cobbold R, Dohnt M, Burns M-A, Jansen C, Leung L-P, Field H, Smythe L. High-resolution melt-curve analysis of random amplified polymorphic DNA (RAPD-HRM) for the characterisation of pathogenic leptospires: intra-serovar divergence, interserovar convergence, and evidence of attenuation in Leptospira reference collections. Annals of Tropical Medicine Parasitology. 2010;104(5):427-37.

20. Miller M, Zorn J, Brielmeier M. High-resolution melting curve analysis for identification of Pasteurellaceae species in experimental animal facilities. PLoS One 2015, 10(11).

21. Codjoe FS, Brown CA, Smith TJ, Miller K, Donkor ES. Genetic relatedness in carbapenem-resistant isolates from clinical specimens in Ghana using ERIC-PCR technique. PLoS One 2019, 14(9).

22. Ohshima C, Takahashi H, Iwakawa A, Kuda T, Kimura B. A novel typing method for Listeria monocytogenes using high-resolution melting analysis (HRMA) of tandem repeat regions. Int J Food Microbiol. 2017;253:36-42.

23. Magyar T, Gyuris É, Ujvári B, Metzner M, Wehmann E. Genotyping of Riemerella anatipestifer by ERICPCR and correlation with serotypes. Avian pathology. 2019;48(1):12-6.

24. Vossen RH: Genotyping DNA variants with high-resolution melting analysis. In: Genotyping. Springer; 2017: 17-28.

25. Wasfi R, Elkhatib WF, Ashour HM. Molecular typing and virulence analysis of multidrug resistant Klebsiella pneumoniae clinical isolates recovered from Egyptian hospitals. Scientific reports. 2016;6:38929.

26. Tsai H-C, Chou M-Y, Wu C-C, Wan M-T, Kuo Y-J, Chen J-S, Huang T-Y, Hsu B-M. Seasonal distribution and genotyping of antibiotic resistant strains of listeria innocua isolated from a river basin categorized by ERIC-PCR. Int J Environ Res Public Health. 2018;15(7):1559.

27. Yang H, Liu T, Zhang G, Chen J, Gu J, Yuan L, He G. Genotyping of Lactobacillus sanfranciscensis isolates from Chinese traditional sourdoughs by multilocus sequence typing and multiplex RAPDPCR. Int J Food Microbiol. 2017;258:50-7.

28. Staji H, Birgani SF, Raeisian B. Comparative clustering and genotyping of Campylobacter jejuni strains isolated from broiler and turkey feces by using RAPD-PCR and ERIC-PCR analysis. Annals of microbiology. 2018;68(11):755-62.

\section{Figures}




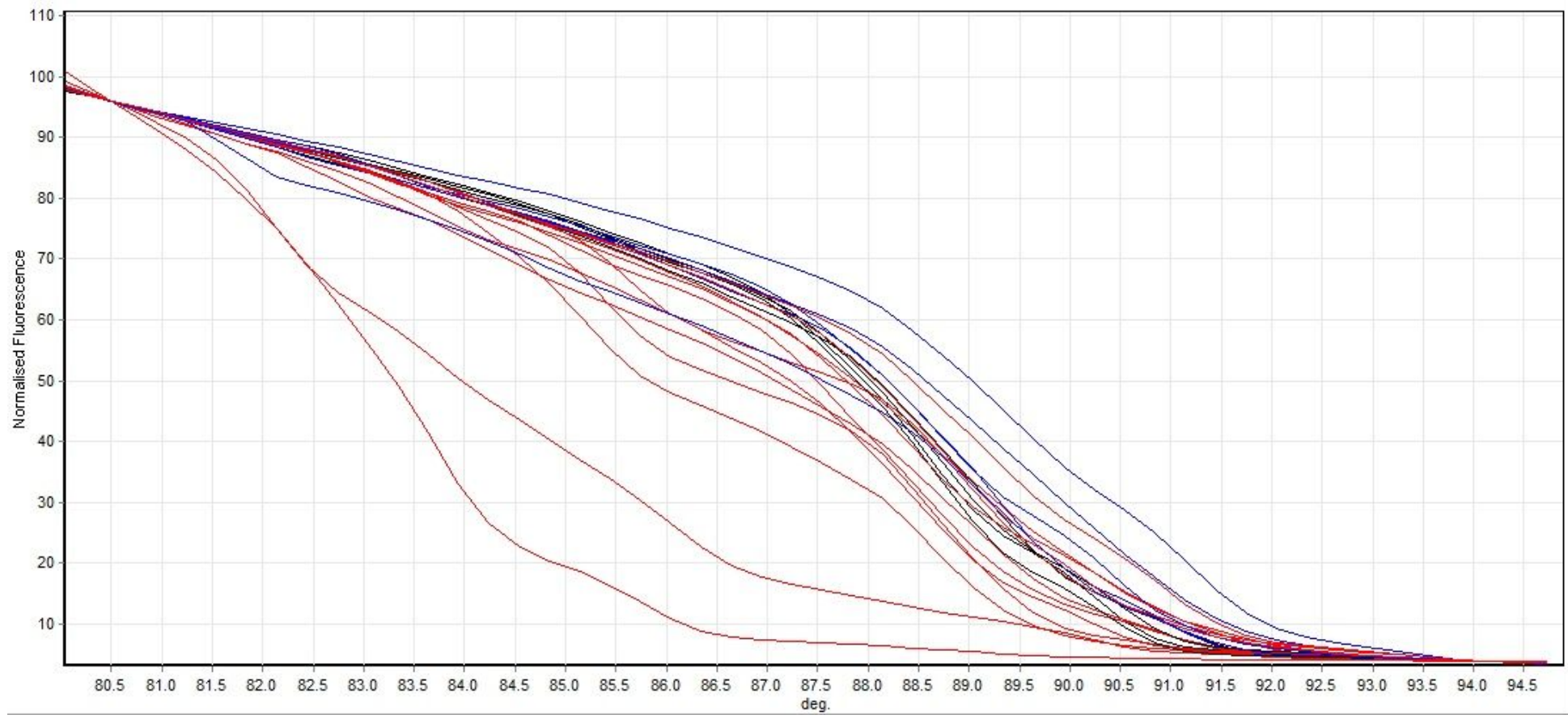

Figure 1

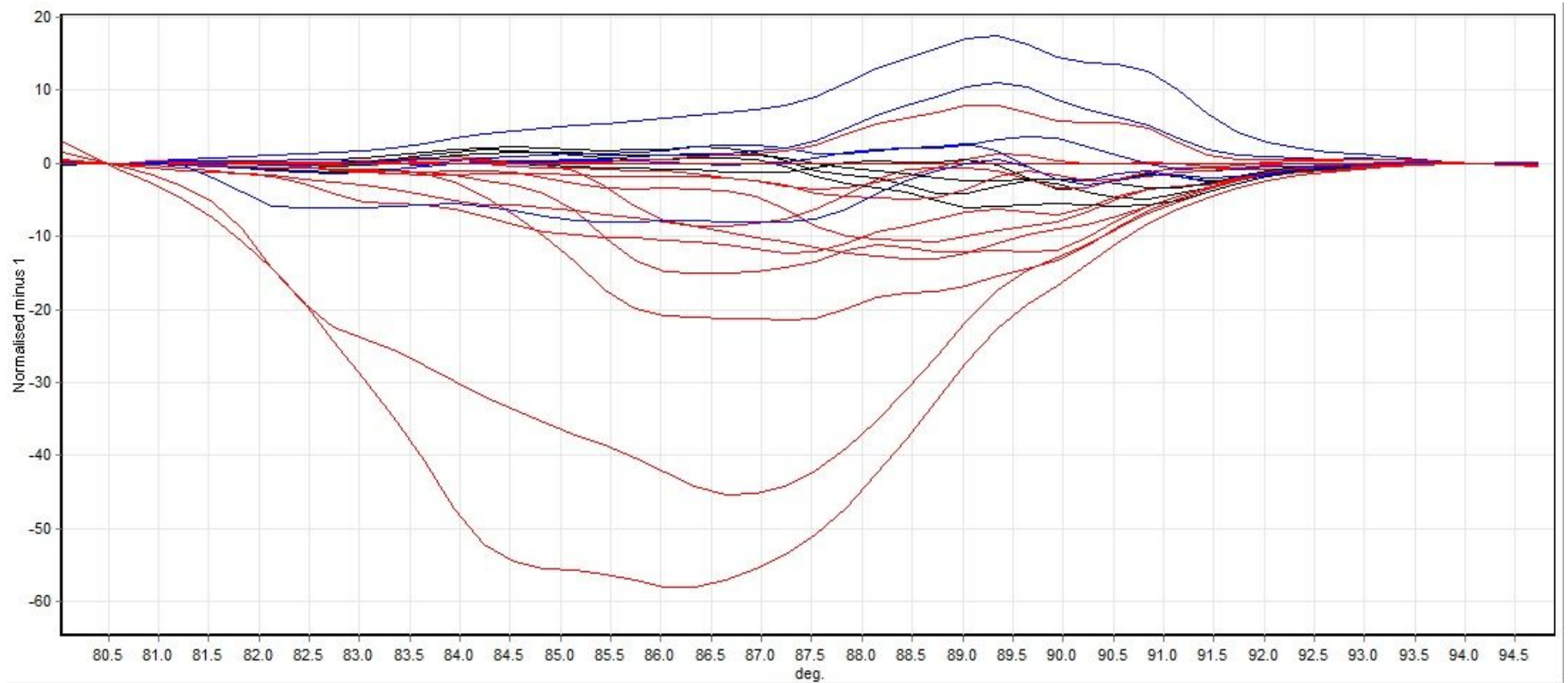

Figure 2 


\section{Component Plot}

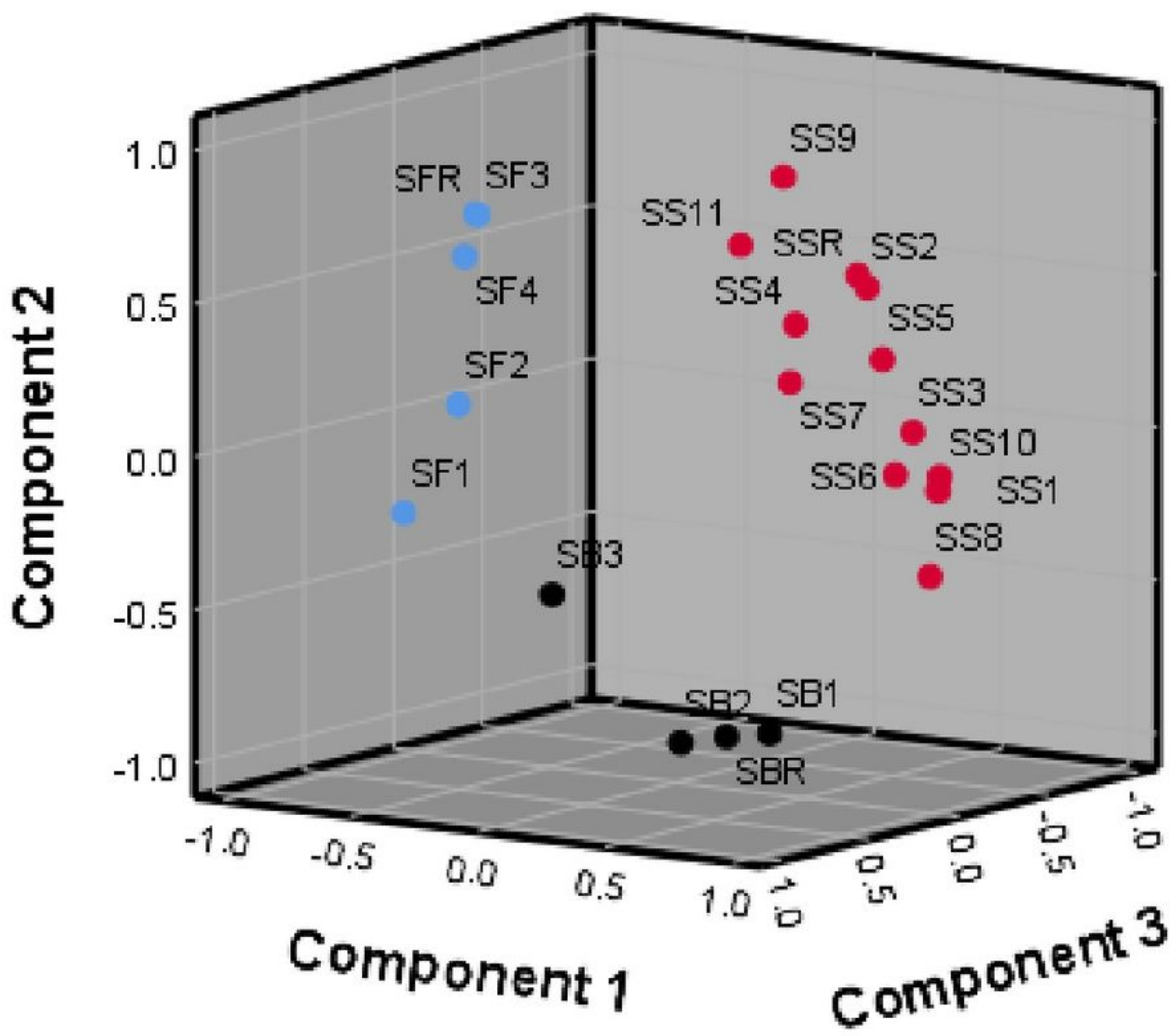

Figure 3 


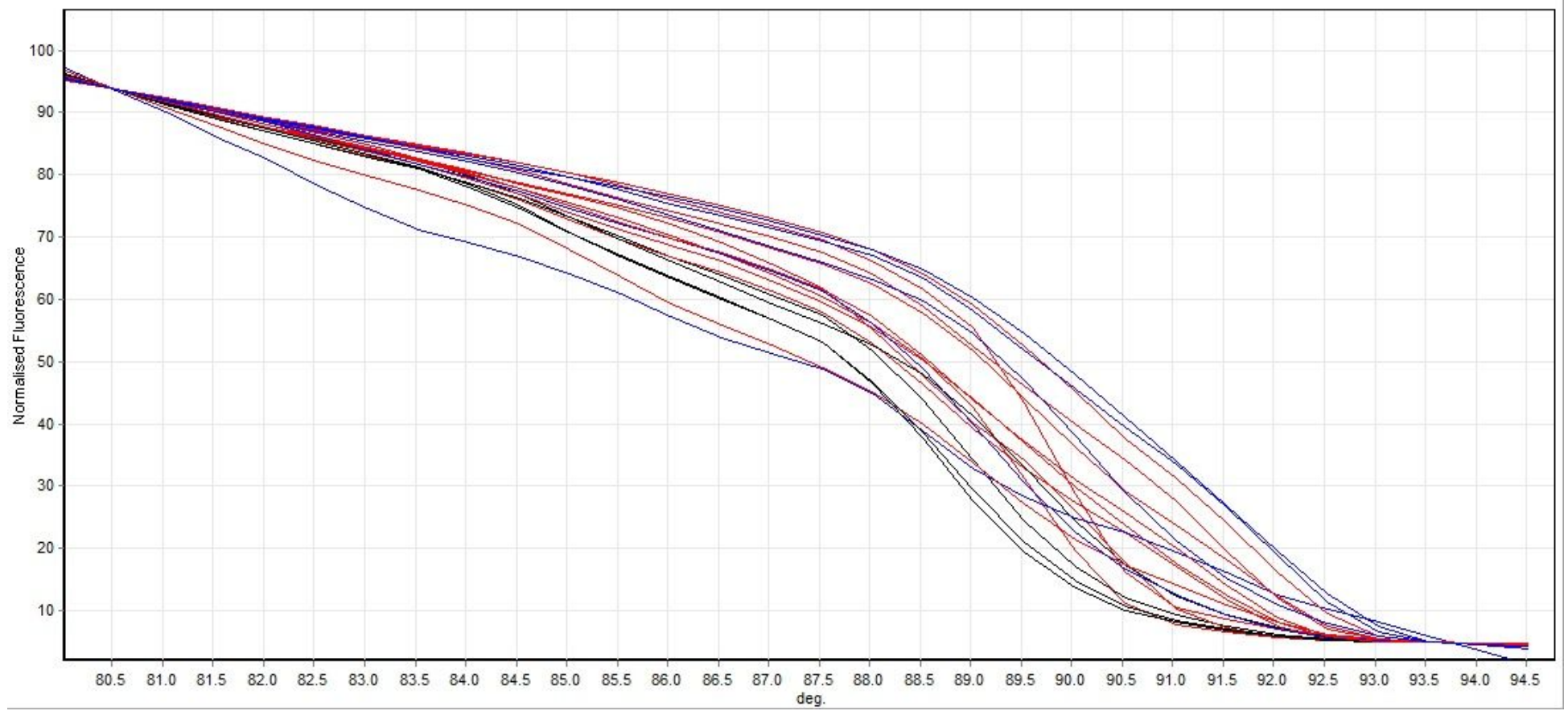

Figure 4

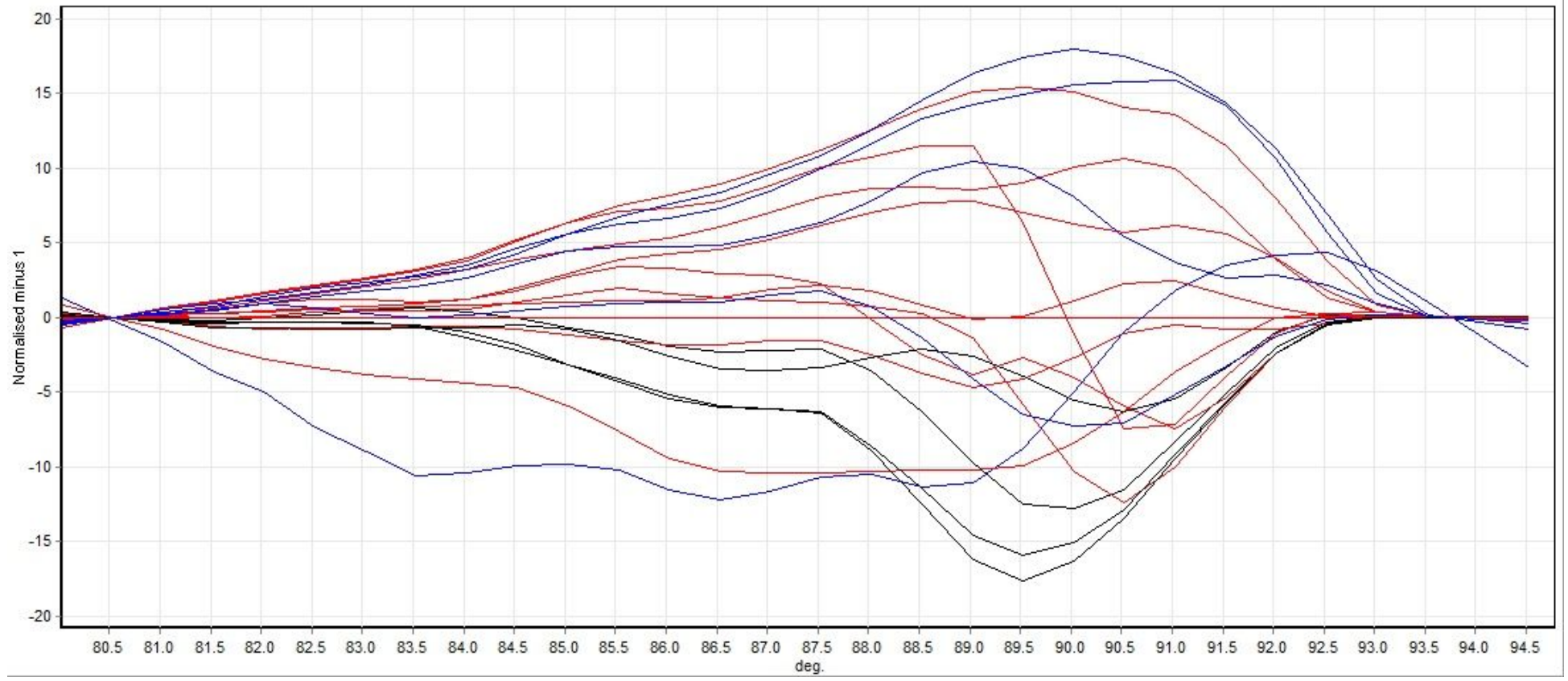

Figure 5 


\section{Component Plot}

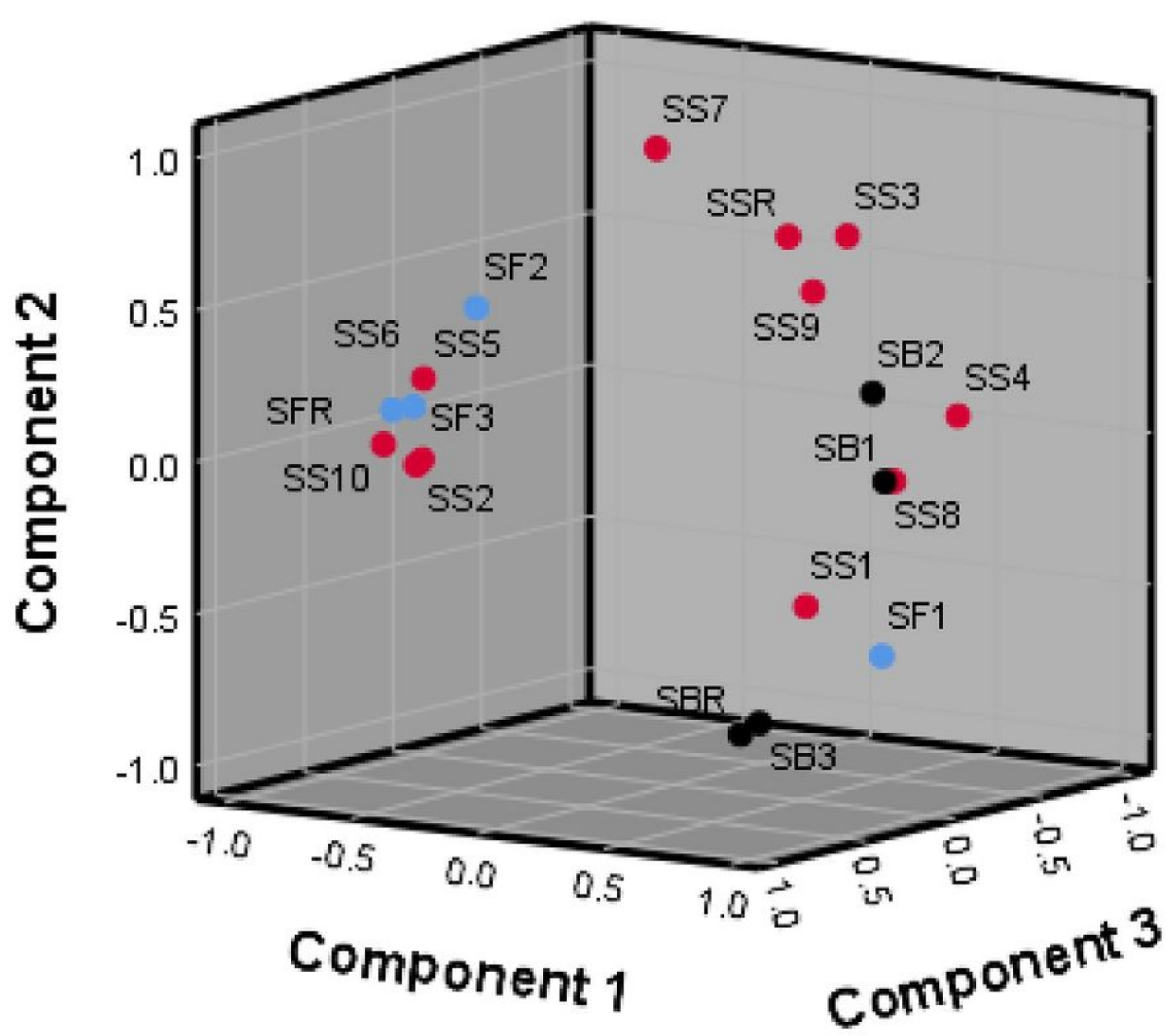

Figure 6 


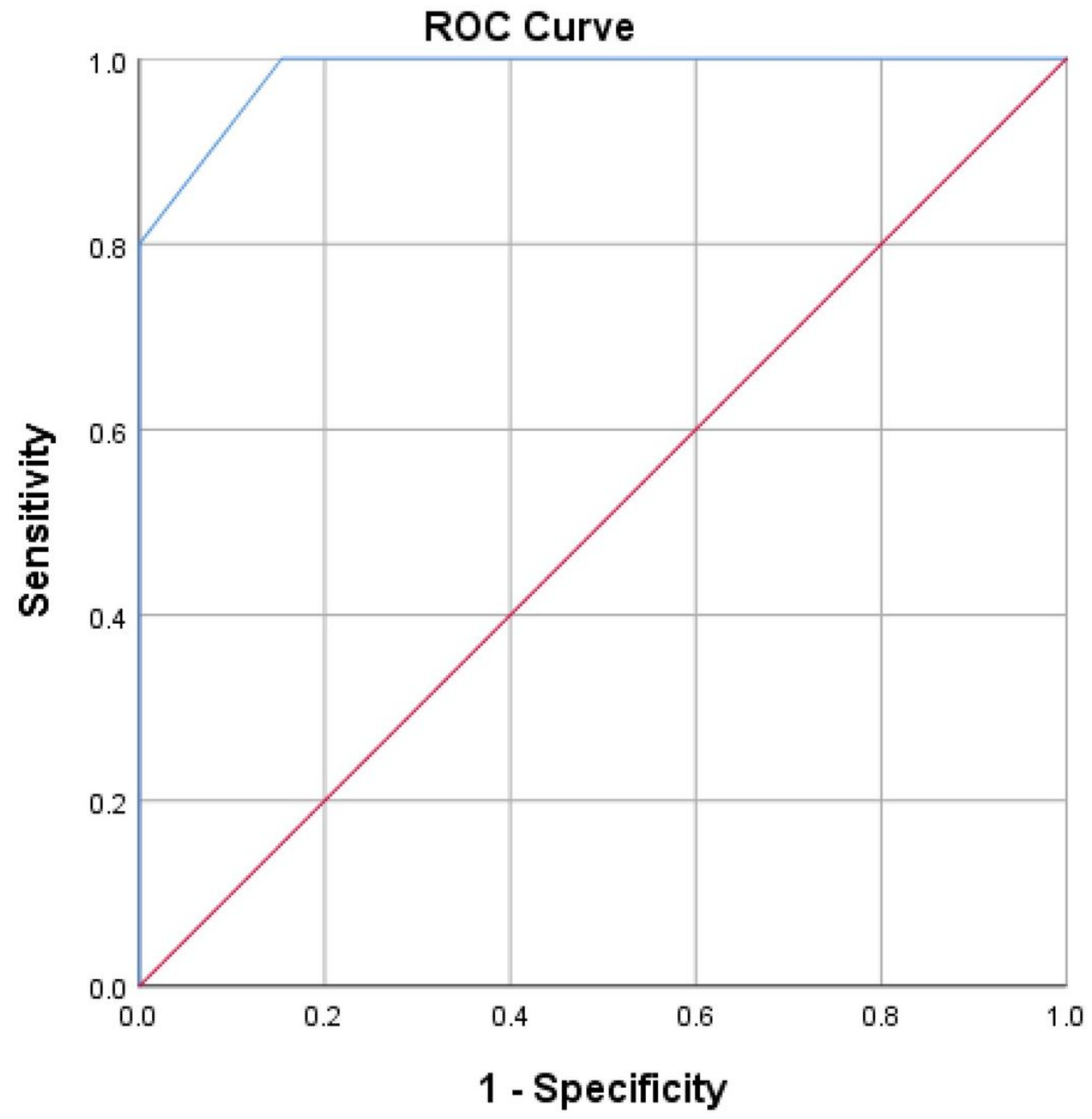

Figure 7 
ROC Curve

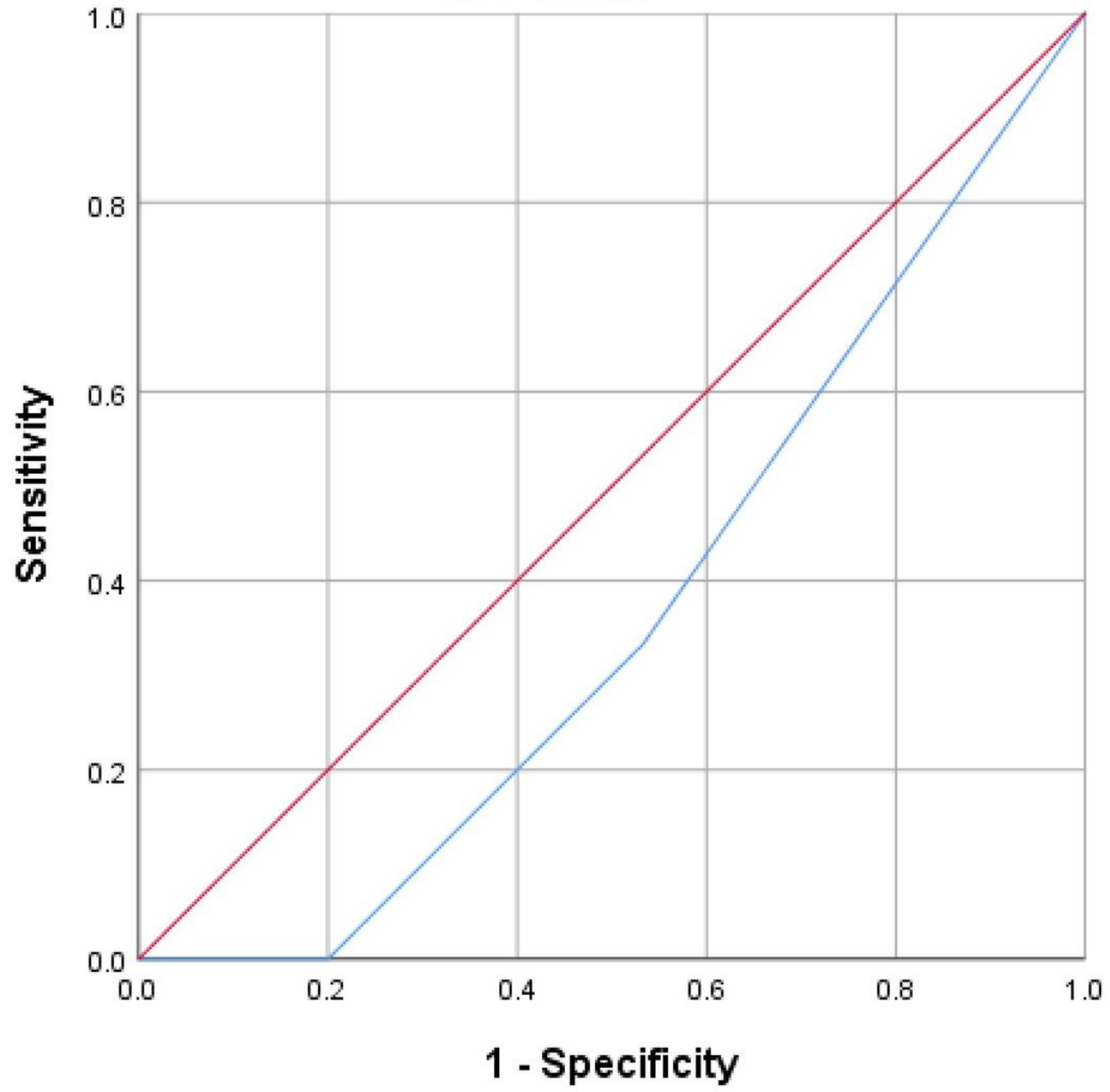

Figure 8 